\title{
A Study of English Listening Strategies by College Students in Web-based Environment
}

\author{
Hong Dang ${ }^{1}$ \\ ${ }^{1}$ Nanyang Institute of Technology, Nanyang, Henan, China, 473004 \\ 87831072@qq.com
}

\begin{abstract}
Keywords: Web-Based Environment, Foreign Language Learning, Listening Strategies, Language Learning Process
\end{abstract}

\begin{abstract}
Resting on the previous research on learning strategies at home and abroad, this thesis will mainly focus on listening strategy use and listening strategy training in web-based self-access environment, comparing them with traditional environment. The author selected 215 non-English majors from four classes in Nanyang Institute of Technology for this study and two classes were assigned as the experimental group and the other two classes as the control group. The experiment consisted of two phases. The first phase is mainly devoted to the analysis of the weaknesses of the strategy use of the subjects. The second phase is concerned with the strategy training and the results followed by the instruction.
\end{abstract}

\section{Introduction}

For most college students of non-English majors, poor listening comprehension has hindered their effective learning processes and their language learning interests. To demonstrate the essential features of the listening process, it is necessary for us to decide what factors are contributing to students' listening difficulty, teaching methods, teaching processes and learning strategies. Traditionally, the situation in college is another factor-the listening comprehension lesson is not being taught but tested. In two years of college English learning (approximately 300 periods) there are 4 periods each week for classroom teaching and only 1 period is devoted to listening instruction. Namely, there are 60 periods more or less for listening instruction in the two years' learning. But the view that listening is merely "passive" or "receptive" is challenged. To demonstrate the essential features of the listening process. it is necessary for us to decide what emphasis should be laid on. In the web-based environment, listening skill, compared with speaking and writing, is relatively easier to be self-taught. Making use of the autonomous learning classroom and encouraging students' autonomous learning is a good choice.

The second purpose of the study is to response the new College English Teaching Reform. The new college English reform requires to develop students' listening ability and their autonomous learning ability in web-based environment. Students need understand the rich computer-cultural connotations; expand the cultural horizons and the input or output of the verbal skill. So this study is to test the abilities of acquiring information about English by using the information technology and facilities.

\section{Review of the Literature}

To begin with, a survey of the literature that is relevant to this study is made. The survey makes clear not only what has been achieved in the relevant fields but also what problems remain to be probed into. Based on it, I narrow down the scope of this study, specify the research issues, and put forward the questions to be tested. After this, I set about a careful planning of the project, taking into account not only critical matters but also great details, and subsequently, put the plan into effect. At the final but the most important stage, the data obtained in the experimental study are processed statistically; the results are discussed; and tentative conclusions are arrived at. 
A review of the literature on listening shows that listening is used far more than other language skills in everyday life and is one of the most important skills in a student's acquisition.

After carrying out a study to language teaching, Ross has laid emphasis on the value of listening to general language development: The consistent fit between the observation data and the results of the listening tests provides adequate evidence to support an approach to TEFL at the elementary level which seeks to educate listening comprehension and communication in the classroom at the same time. Such an approach does not necessarily require a steady stream of teacher talk to create on-the-spot comprehensible input spontaneously. Rather, appropriate listening materials which are calibrated to the interests and abilities of the students are needed for systematic growth in listening skills.

Shuell summarized learning process like this: learners select information from the environment, organize the information, relate it to what they already know, retain what they consider to be important, use the information in appropriate contexts, and reflect on the success of their learning efforts. In the case of second language learning and acquisition, second language learners would also select from the target language input, analyze language functions and forms perceived as important, think about their own learning efforts, anticipate the kinds of language demands they may encounter, and activate prior knowledge and skills to apply to new language learning tasks. This intricate set of mental process of learning has construed foreign and second language learning as a complex cognitive skill (O’Malley and Chamot ).

Rost claims that listening is the key factor in the language classroom because it provides input for the learners. Rost restates that "listening is an essential means of language developments, a point that is often overlooked in language pedagogy and research”. Nunan suggests that listening is assuming greater and greater importance in FL/SL classrooms from both theoretical and practical points of view, because second language acquisition research has given a major boost to listening.

The study of learning strategy in China began in the early 1980s. some Chinese researchers began to study language learning strategies in a foreign language setting under the Chinese culture and language background. One of the most important figures in this field is Professor Wen Qiufang who carried out a series of studies on foreign language learning strategies and training. Since the 1990s, the study in this area made more progress. In 1996, Professor Wen Quifang of the Nanjing University published the book of on English Learning Strategy, which highlighted China's current study in the field of learning strategy. Yang Shuqing's empirical study explores the relationship among sex, grade, career choice, learning style preferences,language learning strategies, and English proficiency of students from public senior high schools in Taipei, China. For strategy training, some researchers have made their contributions. For example, Ji kangli (2002) investigated how metacognitive strategy training might help develop learner autonomy. Zhou Weijing (2002) carried out an experimental study to investigate the effects of strategy training in listening performance. Such studies supported the western research findings: training strategies would result in improvement in language learning. Although more and more researchers in China claimed the interest in this field, the research number was small and the research scope was too narrow. Therefore, the present study calls for more research and work on it.

\section{Studies on Learning Strategy Training}

Learning strategies training, which aims to provide learners with the alternatives from which to make informed choices about what, how, why and when they learn, does contribute a lot to the attainment of autonomy. Since strategy-based instruction can help learners take responsibility for their own learning and become efficient learners, some researchers tried to summarize some models including the specific steps to give students opportunities to practice the strategies they are being taught and raise student awareness of the purpose and principle of strategy use. Models suggested by these researchers share a basic structure, so just two of them by Oxford (1990) and O'Malley and Chamot are introduced here. 
Oxford's model focusing on the teaching of learning strategies is useful for long-term strategy training consisting of eight steps, in which the first five are planning and preparation and the last three involve conducting, evaluating, and revising the training. The other framework, illustrated by Chamot and O'Malley (2001), is especially in a variety of contexts. O’Malley and Chamot's project called Cognitive Academic Language Learning approach (CALLA) emphasize direct language learning strategies instruction. The sequence of instruction in CALLA approach is a five-phase recursive cycle:

1. Preparation focuses on developing students' awareness of different strategies.

2. Presentation involves making students aware of knowledge about proper strategies.

3. Practice concerns developing students' skills in using strategies to find their own solution for academic purposes.

4. Evaluation concentrates on students' ability to evaluate their own performance in strategy application.

5. Expansion tries to develop transfer of strategies to new tasks.

In their works, O’Malley and Chamot summarize some principles of the common procedures for teaching strategies. First, teachers present and explain new strategies,then develop students' awareness of different strategies that they are already using. Teachers might model the strategy. This is followed by practicing it. Finally, students evaluate their performance in strategy application .

\section{Instruments}

In order to find out the effective way of listening learning in WSLE as well as the differences in the listening strategies receptivity among the students of different levels and different groups, four instruments are employed in the present study, namely, listening ability tests, questionnaires, an interview and learning diaries.

Tests on listening comprehension ability are employed to measure students listening improvements spurred by self-access study. Students from both the EG and the CG were administrated two sets of listening tests in terms of pre-test and post-test. The pre-test used is College English Proficiency Tests auto-generated by the Self-access Learning System which was designed and published by Foreign Language Teaching and Research Press.The research aims to investigate examine the Chinese college students' strategies use in web-based self-access environment through using online resources outside the classroom. The modified questionnaire of listening strategy was based on Oxford' s classification of listening strategies and the theories on learner self-access study and listening. The questionnaire consists of two parts: 1) About the learner: gender, age, years for English study, grade; 2 ) listening strategy survey. The students were asked to indicate their response (1=strongly disagree; $2=$ mildly disagree; $3=$ no idea; $4=$ mildly agree; $5=$ strongly agree) to a strategy description.

In order to supervise the students' learning process and find out the difference of strategies use between different groups in EG, EG students were asked to keep a weekly diary to describe what they usually did or thought in listening learning and to write down their listening strategies used in the listening activities in great detail.

Data from pre- and post-tests are analyzed to determine whether there is a correlation between listening strategies training and listening learning achievements in web-based self-access environment; whether strategy training results in improved performance in listening comprehension; and how the listening strategies training affects the listening learning achievements among students from different levels. Independent-Samples $\mathrm{T}$ Test and Paired-sample $\mathrm{T}$ test is used to analyze the data collected from the pre- and post-tests. The Questionnaire on Listening Awareness were administrated twice on the basis of pre- and post-test to the EG to test whether there was increase in listening awareness because of the training. Microsoft Office Excel 2003 and Paired-Samples T Test are used to analyze the data. All the above analysis conform the objective of the research. 


\section{Conclusions}

In the web-based learning environment, the roles of the students and the teacher are quite different from the roles they played in traditional learning environment. Students become the center of learning under this environment . After one semester's training, the experimental group demonstrated superiority over the control group in post-test, which shows that the LST has proved to be successful. Listening strategies training affect language learners at different levels differently. Between the students' listening proficiency improvement and LST , there is a significant positive correlation. Mid-level students can actively construct new knowledge based on their own individual experiences and understandings.

\section{References}

[1] Anderson, N. J., L2 Learning Strategies. In E. Hinkel (ed.). Handbook of Research in Second Language Teaching and Learning. Mahwah [M]. NJ: Lawrence Erbaum Associates, 2005

[2] Benson, P \&Voller, P. (Eds) Autonomy and Independence in Language Learning. London: Longman, 2006

[3] Brown, G. “Dimensions of Difficulty in Listening Comprehension.” D. Mendslshon \& J. Rubin (eds.) A Guide for the Teaching of Second Language Listening. San Diego: Dominie Press, 2010

[4] Cohen, A. D. Strategies in Learning and Using a Second Language. Beijing: Foreign Language Teaching and Research Press, 2000

[5] Cohen, A. D. Strategies in Learning and Using a Second Language. Beijing: Foreign Language Teaching and Research Press, 2000

[6] Nunan, D. Second Language Teaching and Learning. Beijing: Foreign Language and Research Press, 2001

[7] Wen Qiufang, Relationship between EFL learners' controllable factors and their grades [M]. Xi'an: Shanxi Normal University Press. 2004.

[8] Vandergrift, L., Recent developments in second and foreign language listening comprehension research [J]. Language Teaching, 2007 